\title{
The Relationship Between Burnout Syndrome and Organizational Commitment Perception of Employees in Fast Moving Consumer Goods Industry
}

\author{
M. Çağrı PEHLIVANOĞLU (iDa Ertuğrul KÖSE ${ }^{\text {D }}$ b \\ a cpehlivanoglu@yahoo.com \\ b Gübre Fabrikaları Türk A.Ş., İstanbul, Turkey. ertugrulkose73@gmail.com
}

\begin{tabular}{|c|c|}
\hline ARTICLE INFO & ABSTRACT \\
\hline $\begin{array}{l}\text { Keywords: } \\
\text { Burnout Syndrome }\end{array}$ & $\begin{array}{l}\text { Purpose - The aim of this research is to identify the relationship between burnout syndrome and } \\
\text { organizational commitment perception of employees. }\end{array}$ \\
\hline $\begin{array}{l}\text { Organizational Commitment } \\
\text { Fast Moving Consumer Goods } \\
\text { Industry }\end{array}$ & $\begin{array}{l}\text { Design/methodology/approach - Within the framework of the existing literature, two Likert type } \\
\text { scales were used to measure the conceptual structures. The measurement tools were distributed to } \\
475 \text { participants made up of sales employees employed by companies operating in the fast-moving } \\
\text { consumer goods industry in Istanbul. In total, } 445 \text { valid questionnaires were gathered for statistical } \\
\text { analysis. The research was conducted by IBM SPSS } 22.0 \text { and AMOS } 23.0 \text { software. In total, } 10 \\
\text { hypotheses, including all the sub-dimensions, were investigated through statistical analysis. }\end{array}$ \\
\hline $\begin{array}{l}\text { Revised } 21 \text { October } 2020 \\
\text { Accepted } 30 \text { November } 2020\end{array}$ & $\begin{array}{l}\text { Findings - It has been concluded that there is a significant, linear, and negative relationship between } \\
\text { two conceptual structures and their sub-dimensions. It has also been observed that there is a } \\
\text { statistically significant, linear, moderate, and negative correlation between burnout syndrome and } \\
\text { organizational commitment }(r=-0.362, p=0.00<0.05) \text {. }\end{array}$ \\
\hline Research Article & $\begin{array}{l}\text { Discussion - Employees experiencing burnout syndrome have lower levels of organizational } \\
\text { commitment; and therefore, managers should work on reducing the probability of burnout } \\
\text { syndrome of individuals within the organizations. The findings are limited to the perceptions of } 445 \\
\text { employees and the sample consists of employees working in a single industry in Istanbul. The } \\
\text { analysis can be expanded further to cover other industries and employees in the future studies. }\end{array}$ \\
\hline
\end{tabular}

\section{INTRODUCTION}

The success or failure of an organization is closely related to the performance of its employees. Organizational commitment is an important concept to pay attention to maximize the contribution of employees so that sustainable success can be maintained in organizations. All the actions that serve to reinforce the organizational commitment of employees are valuable. The top managements of the organizations generally focus on carrying out practices to increase the organizational commitment level of the employees, to encourage employee productivity, and to make sure that everyone serves for the winning strategy while enjoying themselves at work. However, concerning the ensuring of commitment, working with humans always have some difficulties within the systems. At this point, it is necessary to identify the factors that might have unfavorable impacts. In this study, burnout syndrome is considered to be an important factor that might have a negative relationship with the organizational commitment of employees.

The relationship between burnout syndrome and organizational commitment has been examined by various researchers in the literature. Commitment, which is an emotional feeling, can be towards a person or an institution. According to Mowday et al. (1979: 226), commitment represents something beyond loyalty to an organization and it could be observed from an individual's beliefs, opinions, and actions. Committed employees easily adopt the goals and values of an organization. On the other hand, burnout syndrome leads to a change in the attitudes and behaviors of the employees, and in time, these employees become unable to fulfill the requirements of the job. This syndrome creates unfavorable results not only for the individuals but also for the organizations. There is much empirical research in the field regarding burnout and commitment which support the assertion that burnout and commitment are associated negatively. According to Leiter \& Maslach (1988: 299), burnout leads employees to feel less committed to the organization, less dedicated to achieving organizational goals and more likely to withdraw from work. However, organizations need 
employees with high commitment and low burnout levels to facilitate the reaching of organizational success (Gemlik et al., 2010: 137).

The existing literature highlights that burnout syndrome is generally observed in occupations where there is close contact and interaction between people (Maslach \& Jackson, 1981: 99; Yener et al., 2014: 15). With respect to past knowledge, this research aims to contribute to the literature by focusing on the employees of one of the most human interactive sectors, the fast-moving consumer (FMCG), sales employees at the enterprises in Istanbul. Fast moving consumer goods are consumer packaged goods that people purchase on daily regular basis. This industry includes food and non-food daily consumer products (Vibhuti et al., 2014: 11681169). Research on this subject by working on the FMCG sample is limited, and therefore, the research is expected to contribute to the literature within this context.

In this research, Maslach Burnout Inventory (MBI) developed by Maslach \& Jackson (1981) and Meyer \& Allen's (1991) Three-Component Model of Organizational Commitment Scale (OCS) were used as the measurement tools. The main hypothesis of the research was tested between the overall average scores of two scales, and additionally, the relationships between sub-dimensions of burnout syndrome (emotional exhaustion, depersonalization, and personal accomplishment) and organizational commitment (affective commitment, continuance commitment and normative commitment) were tested.

\section{LITERATURE REVIEW}

\subsection{Burnout Syndrome}

Burnout syndrome results from chronic workplace stress. It is a syndrome of emotional exhaustion and cynicism (Maslach \& Jackson, 1981: 99). Burnout syndrome is not a sudden situation, and it is important to take necessary measures by identifying in due time since it negatively affects the quality of life of the individuals and causes unhappiness (Ardıç \& Polatcı, 2008: 73-75). If the situation is not successfully managed, the effects of the disorder on the individual could get worse, characterized by state of emotional, physical, and mental exhaustion.

The results of burnout syndrome can be multidimensional including physical, psychological, behavioral, and organizational impact. World Health Organization (2020) describes this syndrome through three characteristics: energy depletion, feelings of negativism related to job and reduced professional efficacy. Empirically, Maslach \& Jackson (1981: 102-103) evaluated these aspects of the burnout syndrome with three characteristics: emotional exhaustion, depersonalization, and lack of personal accomplishment. Since it is a widely accepted approach in the literature, the proposed aspects are described in the following paragraphs.

Emotional exhaustion is a state of physical and emotional depletion. In this case, individuals feel psychologically and emotionally overextended and drained by contact with other people (Leiter \& Maslach, 1988: 297). This feeling results from heavy workload, personal demands and continuous stress. This dimension of burnout is characterized as low energy and chronic fatigue. The individual's relationships with other people are minimal at this stage; and the person may develop negative thoughts against other people while thinking that harm might come from others (Lee, 2017: 732).

Depersonalization refers to an unfeeling and a set of callous behaviors towards people (Leiter \& Maslach, 1988: 297). This situation is also called dehumanization (Wright \& Cropanzano, 1998: 486). The individual at this stage tends to adopt a strict, indifferent, and inhumane attitude towards the job and other people he/she meets. Depersonalization is a defense strategy that the individual applies to protect himself/herself from exhaustion and disappointment, and to consciously get away from the psychological tension that he/she is experiencing (Polatçı et al., 2014: 284).

Lack of personal accomplishment is a decrease in the feelings of success related to the job. The individual feels low motivation, and displays carelessness (Demir, 2009: 195). This reduced feeling of accomplishment is the decline in one's feelings of competence and success in working with people (Leiter \& Maslach, 1988: 298). It is the negative self-evaluations of individuals and diminished competence. Such negative feelings are also the symptoms of depression (Bianchi et al., 2019: 39). 


\subsection{Organizational Commitment}

Organizational commitment is not a written formula, but an emotional relationship between the employer and the employee. Employees tend to consider whether their personal goals and values align with the organization or not. Committed employees show positive attitude and motivation towards reaching the overall objectives, support organizational strategy and show willingness to continue working for the organization. A positive employer-employee bond enhances employee efficiency and retention. The harmony between the employee and the organization becomes important in this context.

Numerous studies have been carried out by various researchers to understand the multiple factors that determine the level of employee commitment and the individual demographic factors depending on one another. Many of them also developed scales to measure the components of organizational commitment. Researchers including Etzioni (1961), Kanter (1968), Mowday et al. (1979), O'Reilly \& Chatman (1986), and Allen \& Meyer (1990) worked on organizational commitment and its dimensions. Accordingly, these dimensions are moral commitment, computational commitment, and alienation (Etzioni, 1961); continuance commitment, compliance commitment and control commitment (Kanter, 1968: 500-516); a strong belief in and acceptance of the organization's goals and values, a willingness to exert considerable effort on behalf of the organization, a strong desire to maintain membership in the organization (Mowday et al. 1979: 226); compliance, identification, and internalization (O'Reilly \& Chatman, 1986: 493-498); affective commitment, continuance commitment and normative commitment (Meyer et al., 1993: 544).

Meyer \& Allen (1991: 67) describe organizational commitment as a psychological state that characterizes the employee's relationship with the organization and decision to stay or leave from the organization. Their model was formed based on earlier commitment research and combines different attitude phenomena and measures the employees' attitude toward the organization. Therefore, affective commitment, continuance commitment and normative commitment correspond with different psychological states of organizational commitment, and all should be examined individually to comprehend the conceptual structure.

Affective commitment refers to the individual's emotional attachment, engagement, and integration with the organization. An employee who is affectively committed strongly accepts the goals of the organization and desires to remain in the organization. In Mercurio's (2015: 403) perspective, affective commitment is the core of organizational commitment and it strongly influences work behaviors more than the other components do (p. 403). Affective commitment is the most influential element of organizational commitment and it is one of the most important predictors of work-related behavior. Affective commitment reflects the employee's deep emotional relationship with the organization and develops with the work experiences obtained owing to interaction with senior managers and working groups. Employees with a high level of affective commitment continue to work, show their talents in the best way, and perform their assigned duties (Kim \& Beehr, 2018: 6; Herscovitch \& Meyer, 2002: 475).

Continuance commitment is a measure of the willingness of an employee to continue being a part of the organization. Employees generally act rationally and calculate the cost of leaving. If the cost of leaving the organization has considerable costs, the employees decide to stay in the organization for a longer period. According to Allen \& Meyer (1990: 71), anything that increases the cost of leaving the organization creates continuance commitment and the antecedents of this type of commitment are side bets (or investments) and the availability of alternatives. Therefore, the economic cost of leaving the organization provides insight into continuance commitment (Umukoro \& Egwakhe, 2019: 55).

Normative commitment is where an employee perceives commitment to the organization as a duty and feels obliged to stay. According to Meyer and Parfyonova (2010: 284), normative commitment has two faces named moral duty and indebted obligation. Normative commitment occurs when employees feel that staying in the organization is the right or the moral thing to do. Therefore, employees with high normative commitment stay with the organization because they believe they should do so. If an organization invests in the education and professional development of its employees, the normative commitment of the employees increases. On the other hand, the individuals feel guilty when they want to leave the organization and think that they owe loyalty (Yahaya \& Ebrahim, 2016: 202). 


\subsection{The Relationship Between Burnout Syndrome and Organizational Commitment}

The relationship between burnout syndrome and organizational commitment has been studied by many researchers in the literature. In these studies, besides determining the relationships between the two conceptual structures, the relationships between the sub-dimensions of burnout syndrome and organizational commitment were also examined. Many researchers have reached to the finding indicating that there was a negative relationship between burnout syndrome and organizational commitment. The interpretation of the finding is that organizational commitment of the employees was expected to decrease as burnout perception of the employees increased (Liu et al., 2019: 663; Görür \& Günaydın, 2019: 11; Yaşar \& Özdemir, 2016: 57; Chen $\& Y u, 2014: 396)$.

In studies on examining the relationships between the sub-dimensions of the two theoretical concepts, some negative interactions were also observed. For example, Dinç et al. (2020: 455) determined that continuance commitment provided predictions on emotional exhaustion and depersonalization, affective commitment had a negative effect on depersonalization, and normative commitment had a negative effect on emotional exhaustion. In another research, Caner and Aydintan (2019: 1661) examined the relationship between emotional burnout and affective commitment and found that emotional exhaustion had a negative effect on affective commitment. Similarly, Kerse et al. (2018: 658-659), determined that there was a negative relationship between affective commitment and emotional exhaustion.

\section{RESEARCH METHODOLOGY}

This research is a quantitative study and the data were gathered by means of questionnaires. IBM SPSS 22.0 and AMOS 23.0 software were used in the analysis. Construct validity of the scales were done by using explanatory factor analysis (EFA) and confirmatory factor analysis (CFA). The reliability of the scales was checked by calculating Cronbach's alpha values. Descriptive statistics, explanatory factor analysis and hypotheses were tested with SPSS, and CFA was performed with AMOS. Correlation analysis method was used to determine the relationships between burnout syndrome and organizational commitment and the subdimensions of these two conceptual structures.

\subsection{Research Model and Hypotheses}

The relationships between the total average scores of the scales and all sub-dimensions were tested by correlation analysis in the present study. The hypotheses of the study were determined as follows:

$H_{1}=$ There is a significant, linear, and negative relationship between BS and OC average scores of employees.

$\mathrm{H}_{2}=$ There is a significant, linear, and negative relationship between $E E$ and $A C$ average scores of employees.

$\mathrm{H}_{3}=$ There is a significant, linear, and negative relationship between EE and CC average scores of employees.

$\mathrm{H}_{4}=$ There is a significant, linear, and negative relationship between $E E$ and NC average scores of employees.

$H_{5}=$ There is a significant, linear, and negative relationship between DP and AC average scores of employees.

$H_{6}=$ There is a significant, linear, and negative relationship between DP and CC average scores of employees.

$H_{7}=$ There is a significant, linear, and negative relationship between DP and NC average scores of employees.

$H_{8}=$ There is a significant, linear, and negative relationship between PA and AC average scores of employees.

$H_{9}=$ There is a significant, linear, and negative relationship between $P A$ and CC average scores of employees.

$H_{10}=$ There is a significant, linear, and negative relationship between PA and NC average scores of employees.

\subsection{Measures and Sampling}

The measurement tools consist of three demographic questions and two scales. The first measurement tool is Maslach Burnout Inventory (MBI) developed by Maslach \& Jackson (1981) while the second measurement tool is Meyer \& Allen's (1991) Three-Component Model of Organizational Commitment (OCS). Both scales were translated to Turkish language. MBI has 22 items and three dimensions: Emotional Exhaustion (EE), Depersonalization (DP), and Lack of Personal Accomplishment (PA) (Maslach \& Jackson, 1981: 102-103); whereas OCS has 18 items and three dimensions: Affective Commitment (AC), Continuance Commitment (CC) and Normative Commitment (NC) (Meyer et al., 1993: 544). The items in both scales were collected on a Likert-type 5-level measurement tool and the levels of the scales are as follows: (1) strongly disagree, (2) 
disagree, (3) neither agree nor disagree, (4) agree, (5) strongly agree. The adopted scales will be referred to as $\mathrm{BS}$ and $\mathrm{OC}$ in the further parts of the research.

The universe of the research consists of sales employees working in the FMCG sector companies in Istanbul. It was unable to gather reliable data regarding the number of companies and employees working in this sector. Therefore, to determine the sample size of the research and perform multivariate analysis, a proportional relationship was established between the number of items in the scales and the number of cases. Within this perspective, 10:1 ratio was accepted as the threshold limit for the study. The original MBI scale had 22 items and regarding the given ration, a minimum of 220 cases were needed, whereas the original OCS had 18 items and a minimum of 180 cases were needed for the multivariate statistical analysis. As the result of the analysis, 475 questionnaires were distributed between July-September 2019 by convenience sampling method to the respondents working at the sales functions of the FMCG enterprises in Istanbul. Finally, 445 of the questionnaires were found to be valid for the statistical analysis. The final ratios were 20:1 for BS and 25:1 for OC scales. The distribution of the sample is as follows: 145 managers, 200 non-managers; $10 \%$ of the sample holds a high school degree, $80 \%$ undergraduate degree, $10 \%$ postgraduate degree; and in terms of age, $25 \%$ is between $18-29$ years old, $40 \%$ is between $30-39$ years old, $30 \%$ is between $40-49$ years old, $5 \%$ is over 50 years old.

\subsection{Analyses of Dimensionality, Validity and Reliability}

In the first step, Kaiser Meyer Olkin (KMO) and Barlett sphericity test statistics were calculated to determine the adequacy and suitability of the sample with respect to Beavers et al.'s (2013: 4) statistical perspective where a $\mathrm{KMO}$ value greater than 0.60 with a significant Barlett test statistic is recommended. As a result of the performed analysis, KMO test results and Barlett test statistics (BS=0.836; $p=0.00),(\mathrm{OC}=0.812 ; p=0.00)$ of the sample were found to be appropriate to proceed with the next steps.

In the second step, EFA was applied by involving all the items in the analysis to examine the factorial structure of both scales. Variables having a value of at least 0.40 factor load and which do not have cross loads less than 0.20 between each other were included in the final scales. In the BS, 18 out of 22 of the items passed the threshold levels (EE07, PA01, PA02, PA03), whereas in the OC, 13 out of 18 of the items passed the threshold levels (CC01, CC04, CC05, AC01, AC03). In the original MBI scale, lower scores of personal accomplishments correspond to greater experienced burnout. Therefore, all the items of the Personal Accomplishment subdimension are reversely coded in the BS scale, while this dimension is regarded as Lack of Personal Accomplishment.

In the third step, reliability analysis was performed for the measurement tools by calculating Cronbach's alpha reliability for each scale and sub-dimension to ensure the internal consistency. Cronbach's alpha coefficients should be at least $\alpha \geq 0.70$ (Peterson, 1994: 388). In Table 1, reliability test results are presented, and all the analyzed items were found to be higher than the expected level.

Table 1. Cronbach's Alpha values for Scales and Dimensions

\begin{tabular}{lcc}
\hline \hline Scales and Dimensions & Number of items & Cronbach's Alpha \\
\hline Burnout Syndrome (BS) & 18 & 0.712 \\
Emotional Exhaustion & 8 & 0.900 \\
Depersonalization & 5 & 0.779 \\
Lack of Personal Accomplishment & 5 & 0.905 \\
Organizational Commitment (OC) & 13 & 0.806 \\
Affective Commitment & 4 & 0.701 \\
Continuance Commitment & 3 & 0.716 \\
Normative Commitment & 6 & 0.778 \\
\hline
\end{tabular}

In the fourth step, CFA was applied to determine the convergent validity of the scales by investigating the goodness of fit statistics. The goodness of fit statistics with respect to the recommended value ranges by Bagozzi \& Yi (2012: 28) was found to be satisfying the threshold limits so it was concluded that both scales are in good fit. 
Table 2. The Goodness of Fit Statistics for MBI and OCS

\begin{tabular}{lccccc}
\hline \hline Scales & $\chi 2 / \mathrm{df}<3$ & RMSEA $\leq 0.06$ & CFI $\geq 0.95$ & GFI $\geq 0.95$ & SRMR $<0.08$ \\
\hline 1. BS & 2.761 & 0.045 & 0.961 & 0.962 & 0.074 \\
2. OC & 2.820 & 0.049 & 0.953 & 0.973 & 0.062 \\
\hline
\end{tabular}

\subsection{Tests of Hypotheses}

All the hypotheses of the study were tested with correlation analysis. Correlation analysis was performed to reveal whether there is a relationship between two variables and, if so, to determine the direction and level of the relationship. Prior to the analysis, the prerequisites of the correlation analysis (assumptions of linearity, multivariate normality, and homoscedasticity) were tested and found to meet all the criteria. According to the results of the correlation analysis, burnout syndrome negatively correlates with OC. As shown in Table 3, it was found that there is a statistically significant, linear, moderate, and negative correlation between burnout syndrome and organizational commitment $(r=-0.362, p=0.00<0.05)$. With this result, the main hypothesis of the research has been confirmed. Accordingly, the null hypothesis was rejected and the alternative hypothesis $H_{1}$ was accepted.

The correlations between the sub-dimensions of BS and OC are shown in Table 4. According to the statistical analysis of the correlations between emotional exhaustion and the dimensions of organizational commitment (affective - continuance - normative), a statistically significant, linear and negative correlation was observed between EE and AC $(r=-0.342, p=0.00<0.05)$, EE and CC $(r=-0.393, p=0.00<0.05)$, EE and NC $(r=-0.326, p=$ $0.00<0.05)$ average scores of the employees. With this result, the alternative hypotheses $H_{2}, H_{3}$ and $H_{4}$ were accepted. Similar correlation results were observed in the statistical analysis of the correlations between depersonalization and the dimensions of organizational commitment (affective - continuance - normative). A statistically significant, linear and negative correlation was observed between DP and AC $(r=-0.267, p=0.00$ $<0.05)$, DP and CC $(r=-0.332, p=0.00<0.05)$, DP and NC $(r=-0.365, p=0.00<0.05)$ average scores of the employees. With this result, the alternative hypotheses $H_{5}, H_{6}$ and $H_{7}$ were accepted. Finally, parallel correlation results with the previous analysis were observed in the statistical analysis of the correlations between lack of personal accomplishment and the dimensions of organizational commitment (affective - continuance normative). A statistically significant, linear and negative correlation was observed between PA and AC $(r=-$ $0.374, p=0.00<0.05)$, PA and CC $(r=-0.359, p=0.00<0.05)$, PA and NC $(r=-0.315, p=0.00<0.05)$ average scores of the employees. With this result, the alternative hypotheses $H_{8}, H_{9}$ and $H_{10}$ were accepted.

Table 3. Correlation Coefficients of the Total Average Scores Scales

\begin{tabular}{lccc}
\hline \hline Scales & Number of items & 1 & 2 \\
\hline 1. Burnout Syndrome (BS) & 18 & & \\
2. Organizational Commitment (OC) & 13 & -0.362 & \\
\hline
\end{tabular}

Table 4. Correlation Coefficients of Sub-dimensions of the Scales

\begin{tabular}{lccccccc}
\hline \hline Dimensions & Items & 1 & 2 & 3 & 4 & 5 & 6 \\
\hline 1. Emotional Exhaustion & 8 & 1.000 & & & & & \\
2. Depersonalization & 5 & 0.458 & & & & & \\
3. Lack of Pers. Acc. & 5 & -0.260 & -0.530 & & & & \\
4. Affective Com. & 4 & -0.342 & -0.267 & -0.374 & & & \\
5. Continuance Com. & 3 & -0.393 & -0.332 & -0.359 & 0.391 & & \\
6. Normative Com. & 6 & -0.326 & -0.365 & -0.315 & 0.431 & 0.456 & 1.000 \\
\hline
\end{tabular}

\section{CONCLUSION AND DISCUSSION}

This study aimed to investigate the relationship between burnout syndrome and organizational commitment in sales employees of the FMCG sector. As the result of the research, it was determined that there is a significant, negative, and linear relationship between the burnout syndrome and organizational commitment perceptions of the employees. On the other hand, it was determined that there were statistically significant 
and negative correlations between the sub-dimensions of burnout syndrome and organizational commitment. The findings of the research are consistent with the previous studies in the literature (Akdemir, 2019: 174; Liu et al., 2019: 663; Yaşar \& Özdemir, 2016: 57; Chen \& Yu, 2014: 396). Employees experiencing burnout would be dissatisfied with the job and work with less organizational commitment than before. Nagar (2012: 56) mentions that the organizational outcomes of lowered organizational commitment would be less loyalty, intention to leave and decreased job performance.

In the past, studies in the literature where the link between the three dimensions of burnout and the commitment were investigated yielded similar results. Leiter and Maslach (1988) found that all the dimensions of burnout correlated with organizational commitment by using multiple regression analyses. All results indicate that burnout is expected to lead to reduced organizational commitment. Similarly, Beduk et al. (2015: 3487) determined a negative and significant relationship between organizational commitment and burnout among healthcare industry employees. Enginyurt et al. (2016: 186) found similar results and noted affective commitment as the primary determinant of burnout syndrome; and accordingly, researchers proposed that increasing levels of organizational commitment will lead to decrease in burnout levels.

Since the relationship between burnout syndrome and organizational commitment perception of employees is significant and negative, this research has several recommendations that could help to reduce the risk of unfavorable impacts of burnout syndrome on employees' organizational commitment. First, the negative consequences of burnout have costs in terms of organizational commitment of employees and the top managements of organizations should have a clear understanding of the concept, along with its effects and development stages. Second, to control this negative impact and organizations should work on the prevention of burnout. Therefore, human resources should be closely following up the morale and motivation of the employees and able to detect the employees who might be facing burnout and raise flag to the management on time. Third, all employees should be integrated to the process and all colleagues, chiefs or subordinates should inform the reporting managers and human resources when they observe any low commitment or burnout sign in an individual. Fourth, an organizational environment where all individuals can share their opinions without feeling fear should be created by the top management. Fifth, it would be beneficial to establish a mechanism that supports work-life balance by reducing the workload of employees. Finally, providing employees with psychological guidance opportunities may have a decreasing effect on burnout perceptions.

All the findings are only valid for this research sample. The research has some limitations, and the results need to be evaluated within this framework. Research findings are limited to the perceptions of 445 employees working at FMCG sector in Istanbul. By working on a geographically diverse sample, including other cities and countries, a more comprehensive analysis can be conducted.

\section{REFERENCES}

Akdemir, Ö. A. (2019). The effect of teacher burnout on organizational commitment in Turkish context. Journal of Education and Training Studies, 7(4), 171-179.

Allen, N. J., \& Meyer, J. P. (1990). The measurement and antecedents of affective, continuance and normative commitment to the organization. Journal of Occupational Psychology, 63(1), 1-18.

Ardıç, K., \& Polatcı, S. (2008). Tükenmişlik sendromu akademisyenler üzerinde bir uygulama (GOÜ Örneği). Gazi Üniversitesi İktisadi ve İdari Bilimler Fakültesi Dergisi, 10(2), 69-96.

Bagozzi, R. P., \& Yi, Y. (2012). Specification, evaluation, and interpretation of structural equation models. Journal of the Academy of Marketing Science, 40(1), 8-34.

Beavers, A. S., Lounsbury, J. W., Richards, J. K., Huck, S. W., Skolits , G. J., \& Esquivel, S. L. (2013). Practical considerations for using exploratory factor analysis in educational research. Practical Assessment, Research \& Evaluation, 18(6), 1-13.

Beduk, A., Eryesil, K., \& Esmen, O. (2015). The effect of organizational commitment and burnout on organizational cynicism: A field study in the healthcare industry. World Academy of Science, Engineering and Technology, International Journal of Economics and Management Engineering, 9(10), 3485-3489. 
Bianchi, R., Schonfeld, I. S., \& Laurent, E. (2019). Burnout: Moving beyond the status quo. International Journal of Stress Management, 26(1), 36-45.

Caner, A., \& Aydıntan, B. (2019). Duygusal tükenmişliğin, duygusal bağlllık üzerine etkisi. İşletme Araştırmaları Dergisi, 11(3), 1656-1662.

Chen, C.-F., \& Yu, T. (2014). Effects of positive vs negative forces on the burnout- commitment-turnover relationship. Journal of Service Management, 25(3), 388-410.

Demir, N. (2009). Tükenmişlik sendromunun örgütsel bağlllık ve iş tatmini üzerindeki etkisi. Öneri, 8(32), 193202.

Dinc, M. S., Kuzey, C., Gungormus, A. H., \& Atalay, B. (2020). Burnout among accountants: The role of organisational commitment components. European Journal of International Management, 14(3), 443-460.

Enginyurt, O., Cankaya, S., Aksay, K., Tunc, T., Koc, B., Bas, O., \& Ozer, E. (2016). Relationship between organisational commitment and burnout syndrome: A canonical correlation approach. Australian Health Review, 181-187.

Etzioni, A. (1961). A comparative analysis of complex organizations. New York: Free Press.

Gemlik, N., Ayanoglu Sisman, F., \& Unsal, S. (2010). The relationship between burnout and organizational commitment among health sector staff in Turkey. Journal of Global Strategic Management, 4(2), 137-149.

Görür, D., \& Günaydın, S. C. (2019). Tükenmişlik düzeyinin örgütsel bağlllık üzerindeki etkisi: Bir alüminyum fabrikası örnek olay çalışması. Sağllk ve Yaşam Bilimleri Dergisi, 1(1), 6-12.

Herscovitch, L., \& Meyer, J. P. (2002). Commitment to organizational change: Extension of a three-component model. Journal of Applied Psychology, 87(3), 474-487.

Kanter, R. M. (1968). Commitment and social organization: A study of commitment mechanisms in utopian communities. American Sociology Review, 33(4), 498-517.

Kerse, G., Koçak, D., \& Özdemir, Ş. (2018). Does the perception of job insecurity bring emotional exhaustion? The relationship between job insecurity, affective commitment and emotional exhaustion. Business and Economics Research Journal, 9(3), 651-663.

Kim, M., \& Beehr, T. A. (2018). Empowering leadership: Leading people to be present through affective organizational commitment? The International Journal of Human Resource Management, 1-28.

Lee, H. J. (2017). How emotional intelligence relates to job satisfaction and burnout in public service jobs. International Review of Administrative Sciences, 84(4), 729-745.

Leiter, M. P., \& Maslach, C. (1988). The impact of interpersonal environment on burnout and organizational commitment. Journal Of Organizational Behavior, 9, 297-308.

Liu, W., Zhou, Z. E., \& Che, X. X. (2019). Effect of workplace incivility on OCB through burnout: The moderating role of affective commitment. Journal of Business and Psychology, 34, 657-669.

Maslach, C., \& Jackson, S. E. (1981). The measurement of experienced burnout. Journal of Occupational Behaviour, 2, 99-113.

Mercurio, Z. A. (2015). Affective commitment as a core essence of organizational commitment: An integrative literature review. Human Resource Development Review, 14(4), 389-414.

Meyer, J. P., \& Allen, N. J. (1991). A three-component conceptualization of organizational commitment. Human Resource Management review, 1(1), 61-89.

Meyer, J. P., \& Parfyonova, N. M. (2010). Normative commitment in the workplace: A theoretical analysis and re-conceptualization. Human Resource Management Review, 20, 283-294.

Mowday, R. T., Steers, R. M., \& Porter, L. W. (1979). The measurement of organizational commitment. Journal of Vocational Behavior, 14, 224-247. 
Nagar, K. (2012). Organizational commitment and job satisfaction among teachers during times of burnout. VIKALPA, 37(2), 43-60.

O'Reilly III, C., \& Chatman, J. (1986). Organizational commitment and psychological attachment: The effects of compliance, identification and internalization on prosocial behavior. Journal of Applied Psychology, 71(3), 492-499.

Peterson, R. A. (1994). A meta-analysis of Cronbach's coefficient alpha. Journal of Consumer Research, 21(2), 381391.

Polatçı, S., Ardıç, K., \& Türkan, G. (2014). Bağlılık boyutlarının tükenmişlik boyutları üzerindeki etkisinin incelenmesi. Yönetim ve Ekonomi, 21(2), 281-292.

Umukoro, J. E., \& Egwakhe, A. J. (2019). Job-characteristics dimensions and employee continuance commitment. Global Journal of Management And Business Research, 19(10), 54-65.

Vibhuti, Tyagi, A. K., \& Pandey, V. (2014). A case study on consumer buying behavior towards selected FMCG products. International Journal of scientific research and management, 2(8), 1168-1182.

World Health Organization. (2020, 07 19). Burn-out an "occupational phenomenon": International Classification of Diseases. Retrieved from World Health Organization (WHO): https://www.who.int/mental_health/evidence/burn-out/en/

Wright, T., \& Cropanzano, R. (1998). Emotional exhaustion as a predictor of job performance and voluntary turnover. Journal of Applied Psychology, 83(3), 486-493.

Yahaya, R., \& Ebrahim, F. (2016). Leadership styles and organizational commitment: Literature review. Journal of Management Development, 35(2), 190-216.

Yaşar, O., \& Özdemir, A. (2016). The relationship of organizational cynicism, burnout and organizational commitment: A study on middle school teachers. Eurasian Academy of Sciences Eurasian Business $\mathcal{E}$ Economics Journal, 6(5), 50-61.

Yaşlığlu, M. M. (2017). Sosyal bilimlerde faktör analizi ve geçerlilik: keşfedici ve doğrulayıcı faktör analizlerinin kullanılması. Istanbul University Journal of the School of Business, 46(Special Issue), 74-85.

Yener, D., Oskaybaş, K., \& Dursun, T. (2014). The effects of burnout on organizational commitment in logistics sector. Journal of Business Research-Türk, 6(2), 15-25. 